\title{
Hubungan Umur dan Lamanya Hemodialisis dengan Status Gizi pada Penderita Penyakit Ginjal Kronik yang menjalani Hemodialisis di RS. Dr. M. Djamil Padang
}

\author{
Hannie Qalbina Syaiful ${ }^{1}$, Fadil Oenzil ${ }^{2}$, Rudy Afriant ${ }^{3}$
}

\begin{abstract}
Abstrak
Penyakit Ginjal Kronik (PGK) masih merupakan masalah kesehatan dunia karena prevalensinya yang meningkat, "ireversible" dan progresif. Malnutrisi lebih banyak ditemukan pada PGK. Sebanyak 40\% malnutrisi ditemukan pada penderita pada awal hemodialisis. Penelitian ini bertujuan untuk melihat hubungan umur dan lamanya hemodialisis dengan status gizi pada penderita penyakit ginjal kronik yang menjalani hemodialisis. Ini adalah suatu penelitian Cross Sectional Study yang dilakukan pada bulan Oktober 2013 di Unit Hemodialisis RS Dr. M. Djamil Padang. Telah Diteliti sebanyak 59 orang penderita PGK. Penilaian gizi diukur dengan Lingkaran Lengan Atas (LILA) dan Tebal Lipat Kulit (Skin Fold). Data dianalisa dengan program SPSS. Hasil penelitian memperlihatkan bahwa umur penderita berkisar 22-75 tahun dengan rata-rata 52,39 $\pm 10,39$ tahun dan terbanyak umur 50-59 tahun yaitu sebesar $50,86 \%$. Lamanya menjalani hemodialisis berkisar 1-97 bulan dengan rata-rata 24,54 $\pm 24,69$ bulan. Malnutrisi pada penderita PGK berdasarkan LILA dan Skin Fold, didapatkan berturut-turut 33 orang (55,93\%) dan32 orang (54,24\%). Tidak didapatkan hubungan yang bermakna antara gambaran gizi dengan umur dan lamanya menjalani hemodialisis $(p>0,05, r<1)$. Kesimpulan dari studi ini adalah malnutrisi pada PGK yang menjalani hemodialisis berkisar antara $54,24 \%-55,93 \%$. Tidak terdapat hubungan antara status gizi dengan umur dan lamanya menjalani hemodialisis
\end{abstract}

Kata kunci: PGK, malnutrisi, umur

\section{Abstract}

Chronic Kidney Disease (CKD) is still a global health problem due to its increasing prevalence Its irreversible and progressive state. Malnutrition is more common in CKD patients. A total of $40 \%$ malnutrition case is found in patients at the beginning of their hemodialysis. The objective of this study was to observe the relationships of age and duration of hemodialysis with regard to nutritional status in chronic kidney disease patient on hemodialysis. This was a cross sectional study conducted in October 2013 at Hemodialysis Unit of Dr. M. Djamil General Hospital, Padang. A total of 59 patients with CKD were analyzed. Nutritional assessment was measured by Upper Arm Circles (UAC) and Skin Fold's thickness (Skin Fold). Data were analyzed using SPSS. Results: Ages of patients were ranged from 22-75 years with an average of $52.39 \pm 10.39$ years, and most patients were aged 50-59 years that was equal to $50.86 \%$. The long of hemodialysis was ranged 1-97 months with an average of $24.54 \pm 24.69$ months. Malnutrition in patients with CKD based on UAC and Skin Fold were obtained successively in 33 people (55.93\%) and 32 people (54.24\%). There was no significant association between nutritional figure with age and duration of hemodialysis $(p>0.05, r<1)$. Conclusion from ths study is malnutrition in CKD patients that undergo hemodialysis is ranged from $54.24 \%$ to $55.93 \%$. There is no relationship between nutritional status with age and duration of undergoing hemodialysis.

\section{Keyword: $C K D$, Malnutrition, age}

Affiliasi penulis : 1. Pendidikan Dokter FK UNAND (Fakultas Kedokteran Universitas Andalas Padang), 2. Bagian Biokimia FK UNAND, 3. Bagian IImu Penyakit Dalam FK UNAND/RSUP Dr. M. Djamil Padang
Korespondensi : Hannie Qalbina Syaiful,

email:honey_xiaojie@yahoo.co.id, Telp: 082174156582 


\section{PENDAHULUAN}

Penyakit Ginjal Kronik (PGK) adalah kerusakan ginjal selama 3 bulan atau lebih akibat abnormalitas struktural atau fungsional ginjal, dengan atau tanpa penurunan laju filtrasi glomerulus (LFG) atau, kadar LFG kurang dari $60 \mathrm{~mL} / \mathrm{menit}^{\prime} 1,73 \mathrm{~m}^{2}$ lebih dari 3 bulan dengan atau tanpa kerusakan ginjal. ${ }^{1}$ Klasifikasi PGK bisa dibagi dalam 5 derajat yaitu derajat I, II, III, IV dan V. Derajat V sudah diindikasikan untuk terapi pengganti yaitu dialisis atau cangkok ginjal. ${ }^{1,2}$ PGK masih merupakan masalah kesehatan, karena prevalensinya yang semakin meningkat. $\mathrm{Di}$ Amerika Serikat, data tahun 1995-1999 menyatakan insidens PGK diperkirakan 100 kasus perjuta penduduk pertahun, dan angka ini meningkat sekitar $8 \%$ setiap tahunnya. Di Malaysia, dengan populasi 18 juta, diperkirakan terdapat 1800 kasus baru gagal ginjal pertahunnya. Di negara-negara berkembang lainnya, insiden ini diperkirakan sekitar 40-60 kasus perjuta penduduk per tahun. Di Indonesia, terdapat 400 orang / juta penduduk PGK tahap akhir. Apabila Indonesia mempunyai penduduk \pm 250 juta, berarti ada sekitar 100.000 orang penderita PGK. ${ }^{3}$

Disamping prevalensinya yang semakin meningkat, malnutrisi lebih banyak dijumpai pada penderita PGK yang menjalani hemodialisis dibanding malnutrisi pada populasi umum. Malnutrisi adalah suatu kondisi dimana terjadi kehilangan otot dan cadangan protein visceral, yang pada penderita PGK terutama disebabkan karena asupan nutrisi yang tidak adekuat. Pada penderita PGK, prevalensi malnutrisi ini meningkat secara progresif sejalan dengan hilangnya fungsi residual ginjal. Malnutrisi merupakan keadaan serius pada penderita PGK. ${ }^{4}$

Qureshi AR dkk pada tahun 2002 melakukan penelitian pada 128 penderita PGK yang menjalani hemodialisis dan mendapatkan malnutrisi merupakan penyebab kematian nomor 3 setelah penyakit kardiovaskuler dan infeksi. Pifer TB pada tahun 2002, meninjau ulang sebanyak 7.719 orang penderita PGK yang menjalani hemodialisis di 145 pusat hemodialisis di Amerika dengan hasil kematian $60 \%$ lebih tinggi pada penderita PGK dengan malnutrisi dibanding PGK tanpa malnutrisi. Sebanyak 40\% malnutrisi ditemukan pada penderita PGK pada awal hemodialisis. ${ }^{4}$ Sebanyak $70 \%$ penderita yang telah menjalani hemodialisis dan 50\% PGK yang menjalani peritoneal dialisis. ${ }^{5}$ Malnutrisi merupakan faktor penyebab meningkatnya morbiditas, mortalitas dan menurunnya kualitas hidup. ${ }^{6}$

\section{METODE}

Desain penelitian ini ialah "Cross Sectional Study" yang dilakukan pada bulan Juni 2013 Oktober 2013 di Unit Hemodialisis di RS. Dr. M. Djamil Padang. Kriteria inklusi adalah semua penderita PGK yang menjalani hemodialisis. Kriteria eksklusi adalah penderita yang menolak ikut penelitian, penderita dengan keadaan yang tidak memungkinkan diperiksa BB, TB, LiLA dan Skin Fold misalnya sesak nafas, kesadaran menurun dan lain-lain. Data diolah dan dianalisis dengan menggunakan program SPSS.

\section{HASIL}

Telah dilakukannya penelitian tentang gambaran status gizi pada penderita PGK yang menjalani hemodialisis di unit hemodialisis RS. Dr. M. Djamil pada bulan Oktober 2013. Didapatkan 114 orang penderita PGK yang menjalani hemodialisis. Sebanyak 55 orang dikeluarkan dari penelitian karena kondisi fisik yang tidak bisa diukur BB, TB seperti sesak nafas, stroke, kesadaran menurun, menolak mengikuti penelitian, anak-anak dan VVIP. Sehingga yang mengikuti penelitian sebanyak 59 orang.

\section{Gambaran Data Dasar}

Tabel 1. Distribusi Penderita PGK berdasarkan Umur

\begin{tabular}{ccc}
\hline Kelompok umur & $\mathbf{N}$ & $\%$ \\
\hline$<40$ & 7 & 11,86 \\
\hline $40-49$ & 11 & 18,64 \\
\hline $50-59$ & 30 & 50,86 \\
\hline$\geq 60$ & 11 & 18,64 \\
\hline Jumlah & 59 & 100
\end{tabular}

Keterangan: $\mathrm{n}=$ jumlah

Pada tabel 1 terlihat umur terbanyak penderita PGK yang menjalani hemodialisis adalah 50-59 tahun yaitu sebanyak 30 orang $(50,86 \%)$.

Tabel 2. Distribusi Penderita PGK berdasarkan Jenis Kelamin

\begin{tabular}{ccc}
\hline Jenis Kelamin & $\mathbf{N}$ & $\%$ \\
\hline Laki-laki & 36 & 61,01 \\
\hline Perempuan & 23 & 38,99 \\
\hline Jumlah & 59 & 100 \\
\hline
\end{tabular}


Pada tabel 2 terlihat bahwa 61,01\% penderita dalah laki-laki dan 38,99\% adalah perempuan. Perbandingan laki-laki dan perempuan adalah 1,6:1.

Tabel 3. Distribusi Penderita PGK berdasarkan Lamanya Hemodialisis

\begin{tabular}{ccc}
\hline Lamanya HD & $\mathbf{N}$ & $\%$ \\
\hline$<12$ bulan & 23 & 39 \\
\hline $12-23$ bulan & 15 & 25,42 \\
\hline $24-35$ bulan & 6 & 10,16 \\
\hline$\geq 36$ bulan & 15 & 25,42 \\
\hline Jumlah & 59 & 100 \\
\hline
\end{tabular}

Pada tabel 3 terlihat, 23 orang (39\%) penderita yang menjalani hemodialisis kurang dari 12 bulan. Sedangkan yang menjalani hemodialisis 12 bulan -23 bulan dan $\geq 36$ bulan sebanyak 15 orang $(25,42 \%)$. Dan angka yang paling rendah yaitu 6 orang $(10,16 \%)$ yang menjalani hemodialisis selama 24 bulan - 35 bulan

\section{Gambaran Gizi pada PGK}

Tabel 4. Gambaran Gizi pada Penderita PGK berdasarkan LiLA

\begin{tabular}{cccc}
\hline Gizi & $\begin{array}{c}\text { Laki-laki } \\
\mathbf{n}(\%)\end{array}$ & $\begin{array}{c}\text { Perempuan } \\
\mathbf{n}(\%)\end{array}$ & Jumlah \\
\hline Baik & $15(25,42)$ & $11(18,65)$ & $26(44,07)$ \\
\hline Kurang & $19(32,30)$ & $10(16,95)$ & $29(49,15)$ \\
\hline Jelek & $2(3,39)$ & $2(3,39)$ & $4(6,78)$ \\
\hline Jumlah & $36(61,01)$ & $23(38,99)$ & $59(100)$ \\
\hline
\end{tabular}

Pada tabel 4 terlihat 33 orang (55,93\%) penderita PGK yang menjalani hemodialisis dengan malnutrisi yang terdiri dari 29 orang $(49,15 \%)$ gizi kurang dan 4 orang (6,78\%) dengan gizi jelek. Sebanyak 26 orang (44,07\%) dengan gizi baik. Bila dilihat berdasarkan jenis kelamin, laki-laki lebih banyak mengalami malnutrisi dibandingkan perempuan yaitu 21 orang berbanding 12 orang $(1,75: 1)$.

Tabel 5. Gambaran Gizi pada Penderita PGK berdasarkan Skin Fold

\begin{tabular}{cccc}
\hline Gizi & $\begin{array}{c}\text { Laki-laki } \\
\mathbf{n}(\%)\end{array}$ & $\begin{array}{c}\text { Perempuan } \\
\mathbf{n}(\%)\end{array}$ & Jumlah \\
\hline Baik & $14(23,72)$ & $13(22,04)$ & $27(45,76)$ \\
\hline Kurang & $16(27,12)$ & $6(10,17)$ & $22(37,29)$ \\
\hline Jelek & $6(10,17)$ & $4(6,78)$ & $10(16,95)$ \\
\hline Jumlah & $36(61,01)$ & $23(38,99)$ & $59(100)$ \\
\hline
\end{tabular}

Pada tabel 5 terlihat 32 orang (54,93\%) penderita PGK yang menjalani hemodialisis dengan malnutrisi, yang terdiri dari 22 orang (37,29\%) dengan gizi kurang dan 10 orang (16,95\%) dengan gizi jelek. Sedangkan 27 orang (45,76\%) dengan gizi baik. Bila dilihat berdasarkan jenis kelamin, laki-laki lebih banyak mengalami malnutrisi dibandingkan perempuan yaitu 22 orang berbanding 10 orang $(2,2: 1)$.

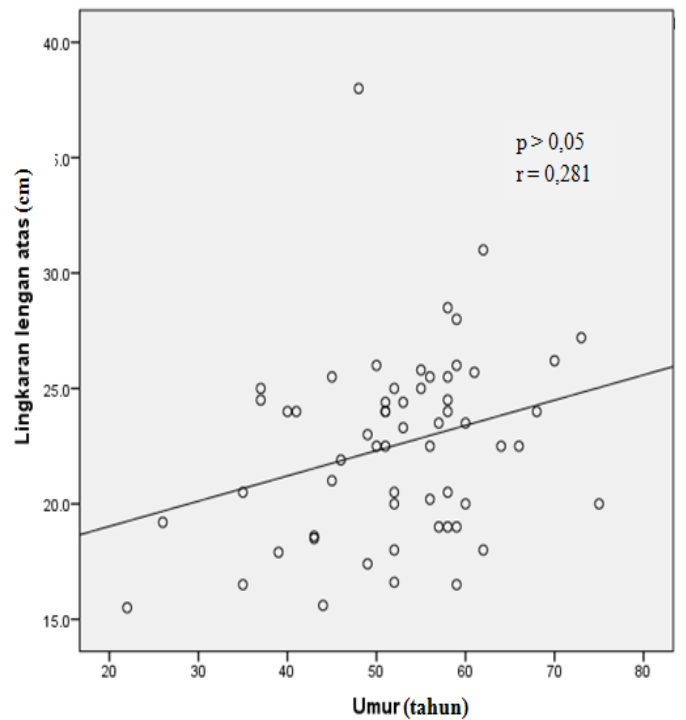

Gambar 1. Hubungan antara LiLA dengan Umur

Pada gambar 1 terlihat hubungan yang positif lemah antara LILA dengan umur, dimana makin bertambah umur maka makin meningkat LILA nya. Namun secara statistik perbedaan ini tidak bermakna ( $p>0,05$ dan $r=0,281)$.

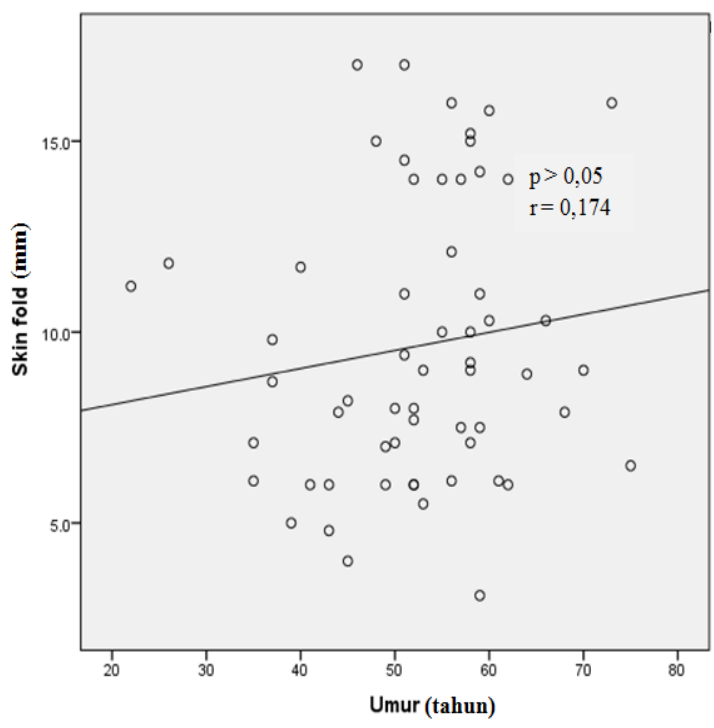

Gambar 2. Hubungan antara Skin Fold dengan Umur 
Pada gambar 2 terlihat hubungan yang positif lemah antara Skinfold dengan umur, dimana makin bertambah umur maka makin meningkat Skinfold. Namun secara statistik perbedaan ini tidak bermakna ( $p>0,05$ dan $r=0,174)$.

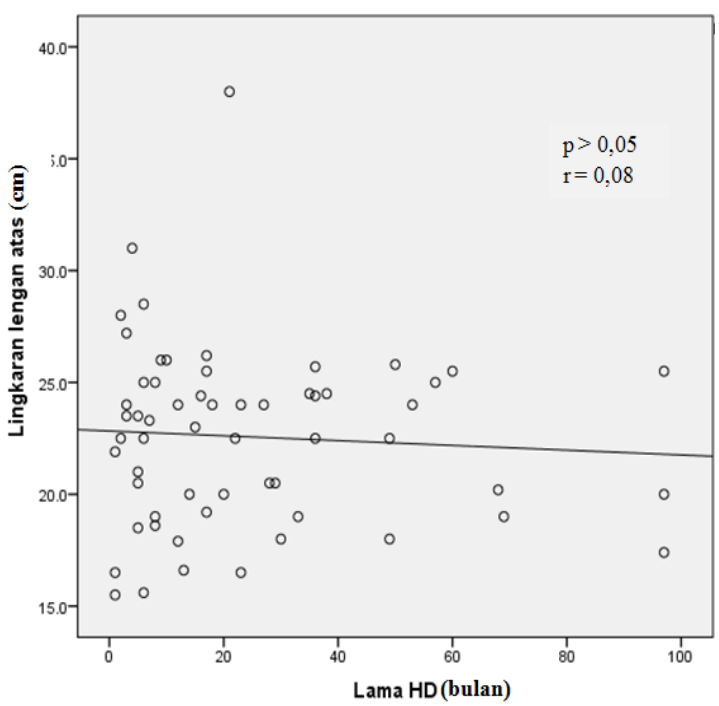

Gambar 3. Hubungan antara LILA dengan Lamanya menjalani Hemodialisis

Pada gambar 3 terlihat hubungan yang negative lemah antara LILA dengan lamanya menjalani hemodialisis, dimana makin lama menjalani hemodialisis maka makin berkurang LILA nya. Namun secara statistik perbedaan ini tidak bermakna $(p>0,05$ dan $r=0,08)$.

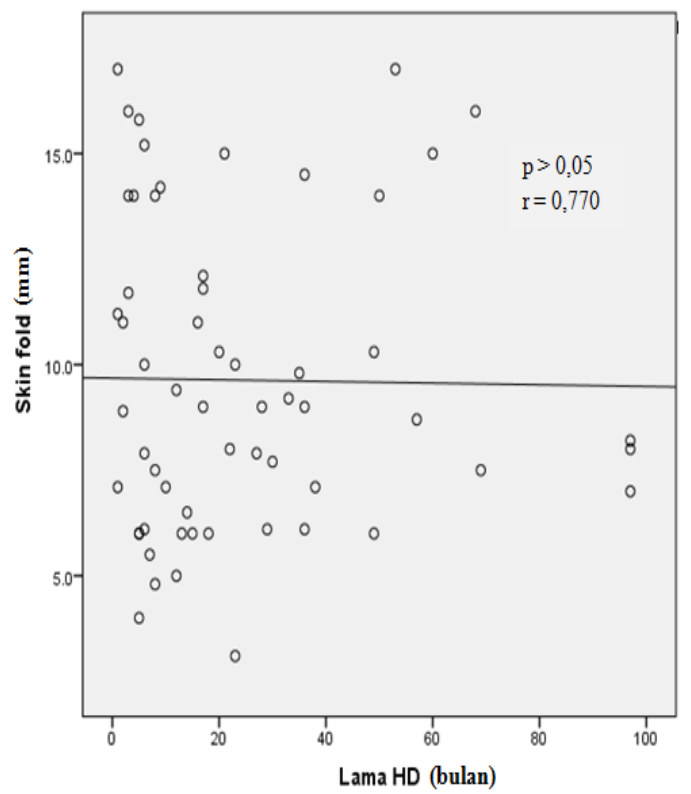

Gambar 4. Hubungan antara Skin Fold dengan Lamanya menjalani Hemodialisis
Pada gambar 4 terlihat hubungan yang negatif lemah antara Skin Fold dengan lamanya menjalani hemodialisis, dimana makin lama menjalani hemodialisis maka makin berkurang Skin Foldnya. Namun secara statistik perbedaan ini tidak bermakna karena $p>0,05$ dan $r=0,770$.

\section{PEMBAHASAN}

Umur

Pada penelitian ini didapatkan umur termuda 22 tahun dan tertua 75 tahun dengan rata-rata umur $52,39 \pm 10,39$ tahun. Rentang usia terbanyak didapatkan pada usia 50-59 tahun yaitu sebesar $50,86 \%$. Keadaan ini sesuai dengan gambaran umum penderita PGK yang menjalani hemodialisis di Indonesia, seperti juga dilaporkan IRR pada tahun 2011 mendapatkan sebanyak 89\% penderita PGK yang menjalani hemodialisis berumur 35-70 tahun dengan kelompok umur terbanyak 45-54 tahun yaitu $27 \%{ }^{8}$

Keadaan yang hampir sama juga dilaporkan oleh Rahimian M, dkk pada tahun 2006 di Pakistan. Rahimian meneliti keadaan gizi pada 60 penderita PGK yang menjalani hemodialisis dengan usia terbanyak 40-60 tahun yaitu sebesar $40 \%{ }^{9}$ Wirhan, dkk pada tahun 2006 meneliti 58 orang penderita PGK yang menjalani hemodialisis dengan rentang usia 3472 tahun. ${ }^{5}$ Kumala M, dkk pada tahun 2008 di Jakarta juga melaporkan 45 penderita PGK dengan umur 48,2 $\pm 7,3$ tahun. Dari empat peneliti diatas nampak bahwa pendertia PGK berusia pada dekade ke 3 sampai 7 .

\section{Jenis Kelamin}

Pada penelitian ini didapatkan 36 orang $(61,01 \%)$ laki-laki dan 23 orang $(38,99 \%)$ perempuan, yang laki-laki berbanding perempuan = 1,6: 1 . Gambaran ini hampir sama dengan penderita PGK yang menjalani hemodialisis di Indonesia. Di Indonesia pada tahun 2011, terdapat sebanyak 6951 orang penderita PGK menjalani hemodialisis, terdiri dari 4180 orang laki-laki dan 2771 orang perempuan, atau laki-laki berbanding perempuan 1,5:1. ${ }^{7}$

Hal yang hampir sama juga didapatkan oleh Wirhan, dkk pada tahun 2006 yang meneliti 58 orang. Penderita PGK yang menjalani hemodialisis dengan perbandingan laki-laki dan perempuan $1,7: 1$. 
Sedangkan Kumala M, dkk pada tahun 2008 di Jakarta melaporkan perbandingan laki-laki dan perempuan 2:1. ${ }^{10}$ Rahimian M, dkk pada tahun 2006 di Pakistan yang meneliti 60 orang penderita PGK yang menjalani hemodialisis juga melaporkan perbandingan laki-laki dan perempuan 1,4:1.

Dari laporan diatas dapat disimpulkan, lakilaki lebih banyak dibanding perempuan menderita PGK yang menjalani hemodialisis.

\section{Gambaran Gizi Penderita PGK}

Gambaran gizi pada penerita PGK yang menjalani hemodialisis bervariasi tergantung kriteria penilaian status gizi yang digunakan. Pada penelitian ini, malnutrisi berkisar antara 54,93\% - 55,39\%. Malnutrisi dengan memakai skinfold sebagai kriteria penilaian gizi didapatkan pada 32 penderita (54,93\%), dan dengan LILA didapatkan malnutrisi pada 34 orang penderita $(55,39 \%)$.

Hal yang sama juga dilaporkankan Wirhan $A$, dkk pada tahun 2006, yang meneliti perubahan gizi pada 41 orang penderita PGK yang menjalani hemodialisis, dimana malnutrisi berkisar antara 30\% - 77,8\%, tergantung kriteria penilaian status gizi. Dengan skin fold, malnutrisi didapatkan sebesar $41,7 \%$, sementara dengan LILA didapatkan $55,6 \%{ }^{5}$

Qureshi, dkk pada tahun 2002 melaporkan sebanyak 128 pasien PGK yang menjalani hemodialisis berkisar antara $23-73 \%{ }^{6}$ Dari hasil penelitian di atas dapat disimpulkan bahwa prevelensi malnutrisi pada penderita PGK yang menjalani hemodialisis tergantung kriteria penilaian status gizi yang digunakan.

Dilihat dari segi jenis kelamin, malnutrisi lebih banyak didapatkan pada laki-laki. Pada penelitian ini sebanyak 21 orang laki-laki dan 12 orang perempuan $(1,75: 1)$ menderita malnutrisi dengan pengukuran gizi berdasarkan LILA dan dengan skinfold didapatkan 22 orang laki-laki dan 10 orang perempuan (2.2 : 1) menderita malnutrisi. Hal yang sama juga dilaporkan oleh Wirhan A, dkk pada tahun 2006 dimana laki-laki lebih banyak menderita malnutrisi dibanding perempuan yaitu $1,7: 1$, Rahiman $\mathrm{M}$, dkk pada tahun 2006 sebesar 1,4: 1 dan Kemala M, dkk pada tahun 2008 melaporkan 2:1. Dapat disimpulkan bahwa lakilaki lebih banyak menderita malnutrisi dibanding perempuan. Hal ini mungkin sejalan dengan prevelensi penderita PGK yang menjalani hemodialisis lebih banyak laki-laki dibanding perempuan, sehingga yang menjalani malnutrisi juga lebih banyak pada lakilaki

\section{Hubungan antara Status Gizi dengan Umur}

Pada penelitian ini tidak terdapat hubungan yang bermakna antara status gizi dengan umur, baik yang penilaian status gizinya dengan Skinfold maupun LILA ( $p>0,05)$. Penelitian tidak mendapatkan referensi sebagai pembanding hubungan status gizi dengan umur pada penderita PGK yang menjalani hemodialisis. Tapi kemungkinan besar hal ini terjadi karena banyak faktor penyebab dari malnutrisi pada penderita PGK yang menjalani hemodialisis.

\section{Hubungan antara Status Gizi dengan Lamanya Hemodialisis}

Pada penelitian ini tidak terdapat hubungan yang bermakna antara status gizi dengan lamanya hemodialisis, baik penilaian status gizinya dengan Skinfold maupun LILA ( $p>0,05)$. Hal yang sama juga dilaporkan oleh Wirhan A, dkk pada tahun 2006, bahwa tidak terdapat perubahan yang bermakna antara status gizi setelah manjalani hemodialisis selama 8 minggu, walaupun kepada penderita telah

\section{KESIMPULAN}

Malnutrisi yang didapatkan berkisar antara 33,9\% - 55,93\%. Dengan pengukuran LiLA, malnutrisi didapatkan 55,93\% dengan perbandingan laki-laki : perempuan $=1,75: 1$. Dengan pengukuran Skin Fold, malnutrisi didapatkan 54,93\% dengan perbandingan laki-laki : perempuan $=2,2: 1$. Penderita PGK yang menjalani hemodialisis berumur 22 - 75 tahun dengan rata-rata 52,39 $\pm 10,39$ tahun. Perbandingan laki-laki dan perempuan $(1,6-2,2): 1$. Lamanya menjalani hemodialisis 1 - 97 bulan mendapatkan rata-rata 25,54 $\pm 24,69$ bulan. Tidak didapatkan hubungan yang bermakna antara umur dengan gizi pada penderita PGK yang menjalani hemodialisis. Tidak didapatkan hubungan yang bermakna antara lamanya hemodialisis dengan gizi pada penderita PGK yang menjalani hemodialisis. 


\section{UCAPAN TERIMA KASIH}

Penelitian ini dapat berlangsung berkat dukungan dari para pembimbing yaitu Prof. dr. Fadil Oenzil, PhD, SpGK dan dr. Rudy Afriant, SpPD. Ucapan terima kasih juga ditujukan kepada Prof. dr. Indrawati Lipoto, PhD, SpGK, dr. Zulda Musyarifah dan perawat hemodialisis yang membantu jalannya penelitian ini.

\section{DAFTAR PUSTAKA}

1. PERNEFRI. Konsensus dialisis. Jakarta; 2003.

2. Suwitra K. Penyakit ginjal kronik. Dalam: Sudowo AW, editor (penyunting). Buku Ajar IImu Penyakit Dalam Jilid I. Edisi ke-4. Jakarta: Departement IImu Penyakit Dalam FKUI; 2006. hlm. 191-200.

3. Dharmeizar. Perawatan gagal ginjal kronis pra hemodialisis. Kumpulan Makalah Annual Meeting. Surabaya; 2002.

4. PERNEFRI. Konsensus nutrisi padap penyakit ginjal kronis. Jakarta; 2011.

5. Wirhan, Pramono B, Asdie AH. The differences of body mass index on depression in type 2 diabetes melitus at DR. Sardijito hospital Yogyakarta. Palembang: The Indonesian Journal of
International Medicine; 2006: 278-80.

6. Qureshi AR, Alvestrand A, Filho JCD, Gutierrez A, Heimburger $\mathrm{O}$, Lindholm $\mathrm{B}$, et al. Inflammation, malnutritional and cardiac disease as predictors of mortality in hemodialysis patient. Journal of The American Society of Nephrologi 13. 2002:S28-S36.

7. Pifer TB, McCullough KP, Port FK, Goodkin DA, Maroni BJ, Held PJ, et al. Mortality risk in hemodialysis patients and changes in nutritional indicators: DOPPS. California: Kidney International; 2002: 2238-45.

8. Indonesian Renal Registry. Report of IRR $4^{\text {th }}$. PERNEFRI; 2011. H 18-19.

9. Rahimian M, Najafi F, Goharian A, Ahmadi AB. A Comparisson of diagnostic value of antrhopometric indices with laboratory criteria for malnutritional detection in chronic undergoing hemodialysis patients. Pakistan Journal of Nutritional. Iran; 2006: 282-5.

10. Kumala M, Lukito W, Sastroamijoyo $S$ and Prodjosudjadi W. Fat free mass index as parameter of nutritional status in non dialysis CKD patients stage 3, 4 and 5 . Med Journal Indonesian. 2008; (17): 40-247. 